\title{
Educação superior privada como serviço de utilidade pública*
}

- Magno Federici Gomes"'

\section{Resumo}

Objetiva-se, com o presente trabalho, o estudo da natureza jurídica da educação superior fornecida pelo segmento privado no Brasil, em conformidade com o ordenamento jurídico brasileiro. Este artigo é preponderantemente teórico-documental. Como conclusão, a partir da evolução constitucional, pôde-se constatar que o direito positivo nacional reconheceu a liberdade de ensino, sob o crivo de um Estado intervencionista e fundante, controlando o sistema educacional por atos administrativos regulatórios, na qualidade de um serviço de utilidade pública. Os atos autorizativos de funcionamento de Instituições de Ensino Superior (IES) não pleiteiam contratos de concessão ou permissão e, consequentemente, dispensam a licitação e a lei instituidora que, em regra, outorga o regime e as qualificações do serviço público, em conformidade com o parágrafo único, do art. 175, da Constituição da República de 1988 (CR/88). A idiossincrasia precária da autorização acaba por prescindir da existência da lei e da licitação. Dessa maneira, no âmbito educacional e mediante exercício do poder de polícia, inexiste liberdade plena da atividade econômica, principalmente com referência ao setor particular.

Palavras-chave: Educação superior privada. Serviço de utilidade pública. Autorização de serviço público. Poder de polícia.

\section{Private Higher Education as service of public utility Abstract}

This work aimed the study of the legal nature of the higher education supplied by the private segment in Brazil, in conformity with the existing dispositions in the national legal ordering. This article is a preponderantly theoretical-documentary work. It has been concluded that, with the constitutional development, the Brazilian positive law recognized the freedom of education, under the trusteeship of an interventionist State, which controls the educational system by regulating

\footnotetext{
" 0 presente artigo é resultado da investigação pós-doutoral em Direito Público, na Universidade Nova de Lisboa, Portugal, fomentada pela Coordenação de Aperfeiçoamento de Pessoal de Nivel Superior, do Ministério de Educação (CAPES) e pela PUC Minas (Pontifícia Universidade Católica de Minas Gerais).

“- Pós-doutor ado em Direito Público e Educação, Universidade Nova de Lisboa, PT; Professor da Pontifícia Universidade Católica (PUC-Minas); Professor Titular da Faculdade de Direito Padre Arnaldo Janssen, Minas Gerais. E-mail:magnofederici@hotmail.com
} 
administrative acts, as service of public utility. The authorization acts of operation of Higher Education Institutions (IES) do not need concession contracts and, consequently, they do not need the procedure of hiring and the law that, as rule, grants the regime and the qualifications of the public service, in conformity with the unique paragraph, of the article 175, of the Constitution of the Republic of 1988 (CR/88). The precarious idiosyncrasy of the authorization finishes doing without the existence of the referred law and the procedure of hiring. Because of that, in the educational scope and through the exercise of the police power, there is no total freedom of the economic activity, specially in relation to the particular sector.

Keywords: Private higher education. Service of public utility. Authorization of public service. Police power.

\section{Enseñanza superior privada como servicio de utilidad pública Resumen}

Se desea, con el presente trabajo, el estudio de la naturaleza jurídica de la enseñanza superior fornecida por el segmento privado en Brasil, en conformidad con el ordenamiento jurídico brasileño. Se trata de un trabajo preponderantemente teórico-documental. Se ha concluido que, con el desarrollo constitucional, se ha podido constatar que el derecho positivo nacional reconoció la libertad de enseñanza, bajo la tutela de un Estado intervencionista, controlando el sistema educacional por actos administrativos reguladores, como un servicio de utilidad pública. Los actos de autorización de funcionamiento de Instituciones de Enseñanza Superior (IES) no necesitan de contratos de concesión y, consecuentemente, dispensan el procedimiento de contratación pública y la ley instituidora que, como regla, otorga el régimen y las calificaciones de servicio público, en conformidad con el párrafo único, del artículo 175, de la Constitución de la República de 1988 (CR/88). La idiosincrasia precaria de la autorización acaba por prescindir de la existencia de la referida ley y de la licitación. De esa manera, en el ámbito educacional y ante el ejercicio del poder de policía, no hay libertad plena de la actividad económica, en especial con referencia al sector particular.

Palabras clave: Enseñanza superior privada. Servicio de utilidad pública. Autorización de servicio público. Poder de policía.

\section{Introdução}

A necessidade de se explicitar a natureza jurídica da educação fornecida pelo segmento privado no Brasil justifica o presente trabalho. Como os atos autorizativos de funcionamento de Instituições de Ensino Superior (IES) não pleiteiam contratos de 
concessão ou permissão e, consequentemente, dispensam a licitação e a lei instituidora que, em regra, outorga o regime e as qualificações do serviço público, em conformidade com o parágrafo único, do art. 175, da Constituição da República de 1988 (CR/88), entende-se que a educação particular não seria uma forma de serviço público, sendo um mero exercício privado da atividade econômica. Assim, objetiva-se solucionar tal dilema, que gera imensos reflexos na interpretação jurídica sobre os dispositivos legais aplicáveis ao ordenamento educacional brasileiro.

A década de 80, segundo Cury (1997a), foi um momento caracterizado pela tentativa de controle da expansão das IES e suas graduações, ante a estagnação do ensino superior público. 0 setor público passou, então, a se empenhar na pós-graduação, para qualificar recursos humanos e consolidar uma comunidade capaz de produzir avanços científicos.

Desse modo, a paralisação do setor público, ressalvada a pós-graduação, termina por se mesclar com o desejo de redemocratização do país, objetivando um verdadeiro Estado Democrático de Direito. A sociedade civil começa a se manifestar para resgatar a dívida social existente, o que gera uma correlação entre Estado e sociedade. Portanto, "o tema da cidadania passa a ocupar o cenário dos anos 80 , culminando na nova ordem jurídica trazida pela Constituição de 1988" (CURY, 1997a, p. 57)'.

A avaliação, em 1988, passou a ser tema relevante após a abertura política, com importante participação docente em sua discussão. A universidade tentou conhecer-se mediante um autodiagnóstico, bem como se legitimar ante uma sociedade ávida por democracia. Cury (1997a) comenta que a avaliação veio para ficar. Exemplo disso foi o Programa de Avaliação da Reforma Universitária (PARU), no início dos anos 80 que, apesar de fracassado, trouxe à tona a temática. Ademais, o Governo da Nova República instituiu a Comissão Nacional para a Reformulação do Ensino Superior, órgão que deu origem, em 1986, ao Grupo Executivo para a Reformulação da Educação Superior (GERES), pois a universidade era instrumento de legitimação do novo governo. De maneira que "instaura-se então um discurso sobre a avaliação, discurso múltiplo e conflitivo, sem que a ele correspondesse uma prática institucionalizada, exceto no nivel da pós-graduação, sob a administração da CAPES/MEC" (CURY, 1997a, p. 58). As referidas iniciativas foram simultâneas à convocação da Assembléia Nacional Constituinte que, também, se debruçou sobre a educação, para aprovar a CR/88 (BRASIL, 1988), em outubro. Manteve-se no art. 206, inciso II, CR/88, a liberdade de aprender e de ensinar, bem como o "livre exercício de qualquer trabalho", no art. $5^{\circ}$, inciso XIII, CR/88. Houve, contudo, uma alteração na coexistência de instituições públicas e privadas de ensino, convertendo a escola livre para a regular, desde que se obedecesse às diretrizes da educação nacional (BRASIL, 1988, art. 22, inciso XXIV) e se submetesse às imposições normativas da autorização e da avaliação de qualidade do Poder Público (BRASIL, 1988, art. 209).

${ }^{1}$ Em sentido equivalente, Vieira (1990, f. 99). 
Para Cury (2005b), a garantia do padrão de qualidade é um princípio constitucional da educação nacional, por estar previsto no art. 206, inciso VII, CR/88 (BRASIL, 1988), e, no caso de oferta de ensino pelo setor privado ele "é, pois, um serviço público autorizado, cuja consequência maior, aliás posta em lei, é o respeito às normas gerais da educação e avaliação de qualidade, de acordo com o art. 209 da Constituição e art. $7^{\circ}$ da LDB" (CURY, 2005b, p. 26) ${ }^{2} 0$ art. 207 CR/88 instaura a autonomia universitária, demonstrando sua identidade e a indissociabilidade essencial entre ensino, pesquisa e extensão. 0 perfil das universidades públicas, principalmente as federais, passa a ser tema de discussão, ante os custos para manutenção e sustentação das grandes universidades, conforme Durham (1993).

A busca pela redemocratização no país, a necessidade de um novo pacto fundamental e a urgência de normas estruturantes democráticas, ensejou, para Cury (2005a), a CR/88 (BRASIL, 1988).

A educação tornou-se o primeiro direito social (BRASIL, 1988, art. 6), como direito civil e político, no respectivo Capítulo, e como dever do Estado, de diversos modos. 0 ensino fundamental é consagrado como direito público subjetivo e o ensino médio, na versão original da CR/88 (BRASIL, 1988), é progressivamente obrigatório. Os sistemas de ensino passam a coexistir em regime de colaboração, no âmbito de suas competências. Institui-se a gratuidade do ensino público em estabelecimentos oficiais (BRASIL, 1988, art. 206, inciso IV), em qualquer nível e etapa. 0 sistema privado deixou de ser uma concessão do Estado e passou ao regime de autorização e de avaliação de sua qualidade (BRASIL, 1988, art. 209, inciso II). 0 corpo docente teve direito à elaboração de seu plano de carreira, a um salário profissional e a cursos para a atualização de conhecimentos, tudo dentro de uma gestão democrática do ensino público.

Manteve-se a competência legislativa privativa da União, posteriormente explicitada pela Emenda Constitucional (EC) no 14 (BRASIL, 1996a) e pela Lei no 9.424 (BRASIL, 1997c), ambas do Fundo de Manutenção e Desenvolvimento do Ensino Fundamental e de Valorização do Magistério (FUNDEF)³, pelas Leis nº 9.394 (BRASIL, 1996b), n०. 10.172 (BRASIL, 2001b), n. 9.131 (BRASIL, 1995c), sobre avaliação do rendimento escolar e institucional e $n^{\circ} .9 .192$ (BRASIL, 1995d), sobre eleição dos dirigentes do ensino público federal, bem como variados atos administrativos normativos.

Depois de dilatada e complicada tramitação, aprovou-se a Lei de Diretrizes e Bases da Educação Nacional (LDB) - Lei no. 9.394 (BRASIL, 1996b), durante o mandato do Presidente Fernando Henrique Cardoso (FHC) e pelo Ministro da Educação e do Desporto, Paulo Renato Souza.

\footnotetext{
${ }^{2}$ No mesmo sentido: Cury $(1997 a, 2003)$. Em sentido equivalente, mas apresentando ressalvas Ranieri (2000). Destaca-se que essa discussão será apresentada e analisada nas próximas partes do presente trabalho.

${ }^{3}$ Atualmente, o FUNDEF foi extinto pela EC nº 53/06 e pela Lei n 11.494/07, ambas relativas ao Fundo de Manutenção e Desenvolvimento da Educação Básica e de Valorização dos Profissionais da Educação (FUNDEB), criado em substituição ao primeiro.
} 
Saviani (2004), Belloni (2003), Vieira (1990) 4 e Ranieri (2000) ${ }^{5}$ explicam que 0 projeto de lei, aprovado na Câmara dos Deputados (PLC), mais precisamente na Comissão de Educação do Senado, em 1993, o substitutivo do senador Cyd Sabóia (Projeto de Lei $n^{\circ} 1.258-C / 88$ ), não veio a se tornar a nova LDB, Lei no 9.394 (BRASIL, 1996b) - Lei Darcy Ribeiro. A referida lei derivou do projeto de lei substitutivo Darcy Ribeiro, devidamente adequado pelo Executivo, daquele período, com suas diretrizes governamentais, antes da sanção e após diversas manobras políticas e regimentais, na Comissão de Constituição e Justiça. Retomam-se na LDB os temas da avaliação e da autonomia. Assim, o projeto de lei substitutivo Darcy Ribeiro, vencedor no conflito parlamentar, incorporou a avaliação como instrumento central e a autonomia como elemento-chave da universidade, segundo Cury (1997b).

Em conformidade com Cury (1997b), o art. 46 da LDB mantém a prerrogativa do Poder Público em autorizar, reconhecer cursos e credenciar instituições, pela mediação de atos administrativos normativos, resguardando o art. 209 CR/88. Portanto, os imperativos constitucionais aparecem na LDB de 1996 (BRASIL, 1996b).

Com isso, para o ensino superior, o governo de FHC instituiu uma política educacional baseada na avaliação, na qualidade da educação, na autonomia universitária, na melhoria do ensino e na ampliação do espaço das IES privadas do citado nivel de educação, segundo Cunha (2003) e Ranieri (2000), o que perdura até os dias atuais. Em sentido equivalente:

A reforma da educação superior faz parte, portanto, de um processo mais amplo e profundo de modernização das instituições sociais com o objetivo de assegurar a hegemonia capitalista a partir de valores produzidos nesta nova etapa deste modo de produção. A modernização das instituições sociais neste momento busca fazer da instituição um espaço social mediador entre as necessidades administrativas do Estado e a subjetividade do indivíduo, como acentua Popkewitz. A produção desta subjetividade realiza-se institucionalmente, daí a necessidade da modernização institucional no Brasil e a profusão de reformas implementadas pelo governo disposto a concretizar seu projeto político (SILVA JÚNIOR; SGUISSARDI, 1997, p. 36-37).

Nesse contexto, o Decreto no 2.306 (BRASIL, 1997b) ${ }^{6}$, derrogou o antigo Decreto $\mathrm{n}^{\circ} 2.207$ (BRASIL, 1997a). Tais atos normativos diversificaram os modelos de ensino superior (universidades, centros universitários, faculdades integradas, faculdades isoladas, institutos superiores ou escolas superiores), posto que se considera a universidade como anacrônica e onerosa, em conformidade com Ribeiro (2002).

\footnotetext{
${ }^{4}$ Tanto Saviani (2004) quanto Belloni (2003), analisam a trajetória da LDB atual por meio de um enfoque educacional.

${ }^{5}$ Para uma abordagem juridica, ver Ranieri (2000, p. 138-141).

${ }^{6}$ Nos dias de hoje, leia-se os Decretos no 5.773 (BRASIL, 2006a) e 5.786 (BRASIL, 2006b), que mantiveram dispositivos quase idênticos aos dos antigos e revogados Decretos n² 2.306 (1997b), nº. 3.860 (BRASIL, 2001), nº 4.914 (BRASIL, 2003) e $n^{\circ}$. 5.225 (BRASIL, 2004).
} 
Morosini (2005, p. 314) ressalta que a universidade acabou por se modernizar no período de 1968 até 1990, por meio da criação dos cursos superiores isolados e da universidade, passando a ter em comum a égide do curso, com organização própria particular e respeitando a normativa federal na qual "as células estruturantes do ensino são os departamentos acadêmicos".

Até metade de 1990, houve a expansão de número e tamanho das instituições de ensino superior, a privatização do setor, a diversificação da comunidade acadêmica e dos cursos, a interiorização de novas instituições, a legitimação de cursos noturnos e em periodos especiais, o aparecimento de instituições multicampi e comunitárias, bem como a expansão das novas universidades do setor privado com orientação empresarial, tudo neste processo de aglutinação.

Morosini (2005) destaca que a fase atual do ensino superior adentra no século XXI. A forte influência da internacionalização no sistema de educação superior acaba por aumentar as discussões sobre os modelos universitários, bem como sobre as tensões, pois a instituição universitária manteve-se imutável, no Brasil e no mundo, desde o século XIX e a Idade Média, respectivamente. A partir de 1990, sofreu transformações radicais, nas quais a perspectiva do Estado-Nação está sendo substituida pela transnacional.

Assim, a relação entre os segmentos público e privado no âmbito do ensino superior não é tema atual. Já se concluiu que "a defesa da contenção dos gastos públicos, em razão do aprofundamento da crise econômica, fora o elemento determinante para tornar a diversificação do sistema de educação superior uma realidade, no plano legal" (RIBEIRO, 2002, p. 12). Em outro trabalho, menciona-se que "público-privado na educação brasileira não é um acontecimento recente. 0 fato do Estado não assumir a educação como um serviço público, uma atividade prioritária, deixou-a vulnerável às pressões de grupos e interesses privados" (PINHEIRO, 1991, f. 46). Assim, muito se discutiu sobre "o papel do Estado na política de privatização desse nivel de ensino" (SOUSA, 2003, f. 28-29).

Este artigo é preponderantemente teórico-documental, pois apresenta a parte legal que trata do tema abordado e faz uma revisão de literatura sobre o objeto de estudo. Trata-se, ademais, de um estudo jurídico-propositivo, porque analisa uma lei e suas falhas, indicando a melhor interpretação a ela cabivel.

\section{0 princípio do interesse público}

Segundo Di Pietro (2004), ao final do século XIX, surgiram reações opostas ao individualismo jurídico, em função de grandes transformações nas ordens econômica, política e social. Assim, individualismo jurídico seria uma conduta que privilegia a pessoa sem considerar o bem-estar da sociedade, como um todo indivisível. Como consequên- 
cia, o Estado começou a intervir na esfera privada, objetivando o bem estar coletivo. Então, "o Direito deixou de ser apenas instrumento de garantia dos direitos do indivíduo e passou a ser visto como meio para consecução da justiça social, do bem comum, do bem-estar coletivo" (DI PIETRO, 2004, p. 69). Em virtude de tal evolução, surgiu 0 princípio do interesse público, também denominado princípio da finalidade pública.

Bandeira de Mello (1998) assevera que o princípio da supremacia do interesse público sobre o privado é um princípio geral de Direito, intrínseco à sociedade, na qualidade de uma condição da sua própria existência. Assim:

[...] não se radica em dispositivo específico algum da Constituição, ainda que inúmeros aludam ou impliquem manifestações concretas dele, como, por exemplo, os princípios da função social da propriedade, da defesa do consumidor ou do meio ambiente (art. 170, III, V e VI), ou em tantos outros. Afinal, o princípio em causa é um pressuposto lógico do convívio social (BANDEIRA DE MELLO, 1998, p. 55).

Bandeira de Mello (1998, p. 55) ainda aponta algumas consequências deste princípio:

[...] em prol da Administração, posição juridicamente correspondente à preponderância do interesse entregue à sua cura. Daí a possibilidade que tem, nos termos da lei, de constituir terceiros em obrigações mediante atos unilaterais. Tais atos são imperativos como quaisquer atos do Estado. Demais disso, trazem consigo a decorrente exigibilidade, traduzida na previsão legal de sanções ou providências indiretas que induzam o administrado a acatá-los. Bastas vezes ensejam, ainda, que a própria Administração possa, por si mesma, executar a pretensão traduzida no ato, sem necessidade de recorrer previamente às vias judiciais para obtê-la. É a chamada auto-executoriedade dos atos administrativos. [...]

Também por força desta posição de supremacia do interesse público e - em consequência - de quem o representa na esfera administrativa, reconhece-se à Administração a possibilidade de revogar os próprios atos inconvenientes ou inoportunos, conquanto dentro de certos limites, assim como o dever de anular os atos inválidos que haja praticado. É o princípio da autotutela dos atos administrativos.

Afirma-se que o termo interesse público, conforme Cunha (2007, p. 32), está associado a outras expressões semelhantes, tais como interesse difuso, geral, coletivo ou utilidade pública, identificando-se "com a idéia de bem comum e reveste-se de aspectos axiológicos, na medida em que se preocupa com a dignidade do ser huma- 
no". Portanto, "a expressão interesse público evoca, imediatamente, a figura do Estado e, mediatamente, aqueles interesses que o Estado 'escolheu' como os mais relevantes, por consultarem aos valores prevalecentes na sociedade" (CUNHA, 2007, p. 32).

Por sua vez, existe definição legal, expressa do princípio do interesse público no art. $2^{\circ}$, caput, parágrafo único, inciso II, Lei no 9.784 (BRASIL, 1999) ${ }^{7}$, sendo uma determinação de "atendimento a fins de interesse geral, vedada a renúncia total ou parcial de poderes ou competências, salvo autorização em lei".

Segundo Di Pietro (2004, p. 68), o princípio da supremacia do interesse público sobre o privado "está presente tanto no momento da elaboração da lei como no momento da sua execução em concreto pela Administração Pública", pois uma das diferenças entre o direito público e o privado reside no interesse que se pretende resguardar, isto é, no primeiro, o interesse público, e no segundo, o individual.

Assim, o princípio da finalidade pública se manifesta em todas as fases do processo legislativo e influencia no conteúdo material da lei originária, de modo a garantir a prevalência dos interesses públicos sobre os individuais. Além disso, a supremacia também aparece nas normas que formularam e outorgaram poder normativo ao Executivo e, consequentemente, nos regulamentos derivados, nos mesmos moldes que nas leis originárias. Nesse sentido, "ocorre que, da mesma forma que esse princípio inspira o legislador ao editar as normas de direito público, também vincula a Administração Pública, ao aplicar a lei, no exercício da função administrativa", apesar de tal princípio não ser "absoluto" (DI PIETRO, 2004, p. 69-70).

A Administração Pública sempre objetiva o interesse coletivo, sem violar os interesses individuais, que, também, devem ser protegidos por via reflexa, respeitando sempre o principio da legalidade.

Destaca-se a existência do princípio da indisponibilidade do interesse público, intimamente vinculado ao da finalidade, cujo significado remonta a:

[...] interesses qualificados como próprios da coletividade - internos ao setor público -, não se encontram à livre disposição de quem quer que seja, por inapropriáveis. 0 próprio órgão administrativo que os representa não tem disponibilidade sobre eles, no sentido de que lhe incumbe apenas curá-los - o que é também um dever - na estrita conformidade do que predispuser a intentio legis (BANDEIRA DE MELLO, 1998, p. 33).

\footnotetext{
${ }^{7}$ Art. 2º, Lei no 9.784 (Brasil, 1999) : A Administração Pública obedecerá, dentre outros, aos princípios da legalidade, finalidade, motivação, razoabilidade, proporcionalidade, moralidade, ampla defesa, contraditório, segurança jurídica, interesse público e eficiência. Parágrafo único. Nos processos administrativos serão observados, entre outros, os critérios de: II - atendimento a fins de interesse geral, vedada a renúncia total ou parcial de poderes ou competências, salvo autorização em lei.
} 
De maneira que a avaliação de qualidade no ensino, em todos os níveis, é uma questão de ordem pública ${ }^{8}$ indisponivel, que resulta do fornecimento da educação, como um direito social. Embora seja obrigação comportamental, não de resultados, segundo Ranieri (2000), a educação se vincula ao princípio constitucional da manutenção do padrão de qualidade (BRASIL, 1988, arts. 206, inciso VII, e 211, § 10), que deve ser assegurado pela Administração Pública. De forma que a educação tem natureza jurídica de função pública, em conformidade com os arts. 205 e 209, incisos I e II, todos da CR/88 (BRASIL, 1988).

Cabe salientar que avaliação educacional e, mais especificamente, a avaliação da aprendizagem visam, resumidamente, a identificar o nivel de qualidade ou efetividade da educação, de forma mais ampla, e do processo de ensino-aprendizagem. Por isso, a educação, como um todo, deve ser diagnosticada e avaliada, tanto no âmbito das políticas, quanto no das IES, conforme art. $3^{\circ}$, inciso IX, LDB, que retoma o art. 206, inciso VII (BRASIL, 1988).

Avaliação de políticas é, em síntese e conformidade com Santos (2000), um ato de verificar a importância de determinações tomadas, para que a condução de alguma estratégia governamental ou prática de alguma intervenção de mesma natureza seja reforçada ou, quando for o caso, corrigida. Por sua vez, a avaliação institucional:

Tem como objetivos levantar informações, fazer diagnósticos de problemas e recomendações que levem à melhoria da qualidade dos processos adotados em uma instituição, programa ou sistema. São verificados o atendimento dos objetivos previstos e a adequação dos recursos alocados. Visa subsidiar o processo de prestação de contas às agências de financiamento, ao poder governamental e ao público em geral. A realização da avaliação, além de verificar a eficiência e eficácia das ações desenvolvidas, visa fornecer diretrizes para a sua melhoria, indicar opções de alocação de recursos e oferecer garantias de que os padrões quantitativos e qualitativos foram alcançados. A avaliação pode desenvolver processos de aferição e de revisão. Os primeiros consistem na medição e registro das informações sobre o funcionamento da instituição, programa ou sistema; processo que pode ser realizado através da auditagem. Esta se refere ao levantamento de indicadores de desempenho com o propósito de assegurar o cumprimento legal das políticas formais ou de monitoramento. Ela segue sistemática padronizada de coleta e registro de informações de entrada e de resultados. Os processos de revisão se referem às informações qualitativas sobre as dinâmicas e desempenhos da instituição, do programa ou do sistema (MARÇAL, 2000b).

\footnotetext{
${ }^{8}$ Expressão empregada como sinônima de interesse público. É paradigmática, em Portugal, a denominação dada ao reconhecimento de curso, qual seja, "reconhecimento de interesse público" de estabelecimento de ensino superior privado, previsto nos arts. 33, 34 e 35, da Lei ${ }^{\circ}$ 62, de 10 de setembro de 2007 (PORTUGAL, 2007).
} 
A mesma autora (MARÇAL, 2000a) define avaliações externa e interna, no âmbito institucional, como modos avaliativos complementares. Quando a avaliação é feita por organizações e especialistas de fora da instituição avaliada, indicados para tanto, a mesma denomina-se externa. Enquanto que a avaliação controlada pela própria instituição em questão, programa ou sistema, é chamada de interna, embora possa ter especialistas externos para gerir o ato.

Em sintese, pode-se dizer que, de modo geral, as avaliações são os instrumentos para o almejado escopo, ou seja, conseguir a tão desejada qualidade no ensino superior.

\section{Educação superior privada como serviço de utilidade pública}

Neste momento, passa-se ao eixo central deste trabalho, que é a explicitação da natureza jurídica da educação fornecida pelo setor privado.

Apesar de não ser atividade exclusiva do Poder Público, a educação satisfaz uma pretensão coletiva, mesmo sob a égide do art. $205 \mathrm{CR} / 88$, o que determina a colaboração mútua do Estado, segmento particular, sociedade e família. Trata-se, portanto, de um serviço público em sentido amplo, pois:

Serviço público é toda atividade que a Administração Pública executa, direta ou indiretamente, para satisfazer à necessidade coletiva, sob regime juridico predominantemente público. Abrange atividades que, por sua essencialidade ou relevância para a coletividade, foram assumidas pelo Estado, com ou sem exclusividade. A própria Constituição Federal é farta em exemplos de serviços públicos, em especial os previstos no artigo 21 com a redação dada pela Emenda Constitucional n 8/95: serviço postal e correio aéreo nacional (inciso $X$ ), serviços de telecomunicações (inciso XI) [...] (DI PIETRO, 2004, p. 60).

Da mesma forma, Meirelles (1997, p. 297) apresenta conceito amplo de serviço público, inclusive por delegação ${ }^{9}$ a concessionários, permissionários e, especialmente, autorizatários, como sendo "todo aquele prestado pela Administração ou por seus delegados, sob normas e controles estatais, para satisfazer necessidades essenciais ou secundárias da coletividade ou simples conveniências do Estado".

\footnotetext{
${ }^{9}$ Ranieri (2000, p. 129) discorda que o ensino fornecido pela iniciativa privada seja uma forma de delegação de serviço público, dando sentido estrito ao referido instituto: "como não se trata de serviço público em sentido estrito, é dizer, não constitui atividade material que a lei considere como tal (embora seja tarefa que corresponda a necessidades coletivas), não há que se falar em delegação para o particular".
} 
Por sua vez, o ensino superior ministrado pela iniciativa privada aparece como serviço de utilidade pública ${ }^{10}$ e a Administração surge como gestora principal do sistema educacional, controlando-o, de modo imperativo, "para garantia das finalidades de desenvolvimento da pessoa humana, seu preparo para o exercício da cidadania e sua qualificação para o trabalho" (RANIERI, 2000, p. 130). A partir da competência legislativa (BRASIL, 1988, arts. 22, inciso XXIV, 24, inciso IX, e seus $\$$ ), o sistema educacional necessita da frequente expedição de atos administrativos normativos regulamentares ou interpretativos. Comenta-se que tais atos são:

[...] emanados pelos diversos órgãos normativos dos sistemas de ensino (Ministério da Educação, Secretarias de Educação, ConseIhos Estaduais e Nacional de Educação etc); bem como estatutos e regimentos institucionais, que encontram fundamento na autonomia universitária (CF, artigo 207) (RANIERI, 2000, p. 130).

Para Bandeira de Mello (1998), ato administrativo é declaração do Estado ou de algum concessionário de serviço público que, ao exercer suas prerrogativas públicas, apresenta medidas jurídicas assessórias da lei, somente para dar cumprimento explícito à mesma, sujeitas, ainda, ao controle jurisdicional. Segundo a doutrina jurídica:

[...] Atos administrativos normativos são aqueles que contêm um comando geral do Executivo, visando à correta aplicação da lei. 0 objetivo imediato de tais atos é explicitar a norma legal a ser observada pela Administração e pelos administrados. Esses atos expressam em minúcia o mandamento abstrato da lei, e o fazem com a mesma normatividade da regra legislativa, embora sejam manifestações tipicamente administrativas. A essa categoria pertencem os decretos regulamentares e os regimentos, bem como as resoluções, deliberações [...] (MEIRELLES, 1997, p. 161)11.

De maneira que, no ordenamento jurídico brasileiro, a regra geral é a existência de atos administrativos normativos executivos, subordinados à lei originária prévia, com algumas exceções, entre elas os arts. 51, inciso IV, 52, inciso XIII, 84, inciso VI, alínea "a", e 96, inciso I, alínea "b", todos da CR/88 (BRASIL, 1988). Entretanto:

[...] alguns órgãos ainda hoje dispõem de competência normativa, porque a legislação que a delegava, antes da Constituição de 1988, teve o prazo de vigência prorrogado por lei, tal como previsto expressamente no artigo 25 das Disposições Transitórias. Fora dessas hipóteses, os demais órgãos administrativos que continuam a exercer função normativa, dis-

\footnotetext{
${ }^{10}$ Serviços de utilidade pública "são os que a Administração, reconhecendo sua conveniência (não essencialidade, nem necessidade) para os membros da coletividade, presta-os diretamente ou aquiesce em que sejam prestados por terceiros (concessionários, permissionários ou autorizatários), nas condições regulamentadas e sob seu controle, mas por conta e risco dos prestadores, mediante remuneração dos usuários. São exemplos dessa modalidade os serviços de transporte coletivo, energia elétrica, gás, telefone" (MEIRELLES, 1997, p. 298-299).

11 No mesmo sentido, Di Pietro (2004, p. 184-216); Caupers (2000, p. 207-209).
} 
pondo sobre matéria reservada à lei ou ao regulamento, não mais dispõem desse poder e as normas que editam padecem do vício de inconstitucionalidade.

Há que se lembrar que, em matéria de telecomunicações e de petróleo, as Emendas Constitucionais n 8/95 e 9/95 alteraram, respectivamente, a redação dos artigos $21, \mathrm{XI}$, e $177, \S 2^{\circ}$, III, para prever a promulgação de lei que disponha sobre a exploração dessas atividades e a instituição de seu órgão regulador ${ }^{12}$. Com base nesses dispositivos, foram criadas a Agência Nacional de Telecomunicações Anatel (Lei no 9.472, de 26-12-96) e a Agência Nacional do Petróleo - ANP (Lei no 9.478, de 6-8-97). Além disso, leis ordinárias foram criando outras agências reguladoras, algumas com funções ligadas a concessões, como é o caso da Agência Nacional de Energia Elétrica - Aneel (Lei no 9.427, de 26-12-96), outras com funções de polícia em áreas específicas, a exemplo da Agência Nacional de Águas - ANA (Lei no 9.984, de 17-7-2000), Agência Nacional de Vigilância Sanitária - Anvisa (Lei no 9.782, de 26-1-99), Agência Nacional de Saúde Suplementar - ANS (Lei no 9.961, de 291-2000), além de agências criadas nos âmbitos estadual e municipal. Isso significa que esses órgãos reguladores exercerão função normativa, porém dentro dos limites do princípio da legalidade [...] (DI PIETRO, 2004, p. 89).

Assim, chama a atenção que, a exemplo dos órgãos reguladores que também possuem competência normativa, houve a aprovação de leis específicas, outorgando função regulamentar ao Conselho Nacional de Educação (CNE) e ao Ministro de Estado da Educação (Leis nº 9.131/95, 9.394/96, 10.172/01 e 10.861/04), já na vigência da CR/88 (BRASIL, 1988), o que cumpre com o princípio da legalidade (art. $5^{\circ}$, inciso II, CR/88). Destaca-se que a Lei $n^{\circ} 9.131$ (BRASIL, 1995c) é anterior a todas as leis federais que atribuíram função normativa às agências reguladoras ${ }^{13}$, após a promulgação da CR/88 (BRASIL, 1988), podendo ser considerada a primeira de muitas outras ${ }^{14}$, o que inaugurou um regime jurídico próprio para tais órgãos, entre eles o $\mathrm{CNE}^{15}$.

\footnotetext{
${ }^{12}$ É sabido que o exercício de funções normativas pela Administração Pública, direta ou indireta, não é algo inovador no ordenamento jurídico brasileiro, antes mesmo das ECs n $8 / 95$ e 19/98. Exemplifica-se a referida afirmação com as hipóteses da Comissão de Valores Mobiliários, com o Conselho Monetário Nacional (Lei $n^{\circ}$ 6.385/76) e com o Conselho Nacional de Petróleo (Decreto-lei no 538/38).

${ }^{13}$ Di Pietro (2004), de acordo com uma análise meramente cronológica.

${ }^{14}$ Citam-se a Agência Nacional de Telecomunicações - Anatel (Lei no 9.472/96), a Agência Nacional do Petróleo - ANP (Lei ${ }^{\circ}$ 9.478/97), a Agência Nacional de Energia Elétrica - Aneel (Lei no 9.427/96), a Agência Nacional de Águas - ANA (Lei no $9.984 /$ 00), a Agência Nacional de Vigilância Sanitária - Anvisa (Lei no 9.782/99) e a Agência Nacional de Saúde Suplementar - ANS (Lei no 9.961/00), todas elas com função normativa, respeitando-se sempre o princípio da legalidade. Ressalva à Comissão de Valores Mobiliários, ao Conselho Monetário Nacional - Lei ${ }^{\circ}$ 6.385/76 - e ao Conselho Nacional de Petróleo - Decreto-lei ${ }^{\circ}$ 538/38, que foram anteriores à CR/88 (BRASIL, 1988).

${ }^{15}$ Em sentido equivalente, Ranieri (2000, p. 229) ao mencionar que "há ainda a possibilidade de os Conselhos de Educação, órgãos normativos e fiscalizadores do sistema educacional, serem qualificados como agências reguladoras mediante a lei".
} 
Coloca-se de manifesto, ainda, que algumas agências reguladoras estavam ligadas a concessões de serviço público, o que também pode ser aplicado, analogicamente, ao ensino fornecido pelo segmento particular, posto que a oferta de ensino pelo setor privado "é, pois, um serviço público autorizado, cuja consequência maior, aliás posta em lei, é o respeito às normas gerais da educação e avaliação de qualidade, de acordo com o art. 209 da Constituição e art. $7^{\circ}$ da LDB"(CURY, 2005b, p. 26, 1997a) ${ }^{16}$.

Em apertada síntese, os órgãos responsáveis pela regulamentação da Educação brasileira, sem prejuízo do Ministério da Educação (MEC) da época, foram, sucessivamente, o Conselho de Instrução Superior (Decreto $n^{\circ} 1232-\mathrm{G}$, de 2 de janeiro de 1891), o Conselho Superior do Ensino (Decreto no 8.659, de 5 de abril de 1911), o Conselho Nacional de Ensino (CNEn) e seu Departamento Nacional de Ensino (Decreto no 16.782, de 13 de janeiro de 1925), o antigo Conselho Nacional de Educação (CNE) (Decreto no 19.850, de 11 de abril de 1931), o Conselho Federal de Educação (Lei n ${ }^{\circ}$ 4.024/61) e, finalmente, o atual CNE, segundo Medidas Provisórias (MPvs) posteriormente convertidas na Lei no 9.131 (BRASIL, 1995c).

Como analisado, o principal objetivo da relação educacional é a formação do aluno, o que é seu direito individual. Por isso, o interesse público é que a educação fornecida pelas IES seja de qualidade, tornando efetivo o processo de ensino e de aprendizagem no nível superior. Para isso, é de extrema importância que os procedimentos de avaliação das IES assegurem a qualidade das mesmas, seja na autorização, no reconhecimento ou no credenciamento das referidas instituições, bem como nos procedimentos administrativos de supervisão e avaliação do Sistema Nacional de Avaliação da Educação Superior (SINAES).

Para que a coletividade seja atendida e beneficiada (cidadãos e sociedade), é indispensável que seja procedida a avaliação qualitativa das IES, dando cumprimento ao Decreto $n^{\circ} 5.773$ (BRASIL, 2006a) e ao ordenamento infraconstitucional, sem prejuízo de futuras inovações nos procedimentos avaliativos, quando se mostrarem necessárias à eficácia plena dos arts. 206, inciso VII, 209, inciso II, e 211, § $1^{\circ}$ (BRASIL, 1988). Para tanto, é conveniente que as mantenedoras das IES estejam preparadas para aceitar as cominações do princípio da supremacia do interesse público sobre o privado. Em sentido semelhante:

A submissão da atividade ao regime publicístico, portanto, se faz mais em razão da natureza do órgão prestador e dos recursos que a financiam que para proteção material da finalidade pública, nesta situação identificada ideologicamente com a noção de bem comum (RANIERI, 2000, p. 133).

${ }^{16}$ Em sentido equivalente, mas com ressalvas, Ranieri (2000). 
É muito importante repisar, em função da natureza jurídica do ensino privado como um serviço de utilidade pública, que o fornecimento da educação, pelos segmentos público ou particular, incide em dispositivos cogentes, dotados de caracteristicas inerentes ao interesse público indisponivel, tais como os arts. 170, caput e seu parágrafo único, 206, inciso VII, 209, incisos I e II, e 211, § 10, CR/88 e as Leis $n^{\circ}$ 9.131 (BRASIL, 1995c), n. 9.394 (BRASIL, 1996b), $n^{\circ} .10 .172$ (BRASIL, 2001b) e $n^{\circ}$. 10.861 (BRASIL, 2004b), segundo os quais o Poder Público regulamenta as condições da atividade de ensino e a controla por meio dos procedimentos avaliativos primários de autorização de cursos superiores e credenciamento de IES, bem como nos secundários, relativos ao reconhecimento de cursos e às renovações das qualificações antes indicadas, todos previstos no Decreto n. 5.773 (BRASIL, 2006a) e em outros atos administrativos normativos. Com isso:

A natureza pública da atividade educacional na esfera privada determina a derrogação parcial de prerrogativas inerentes ao regime privatístico por normas de direito público, dada a prevalência da finalidade pública sobre o interesse particular, muito embora ambos se confundam em face dos fins da atividade educacional (RANIERI, 2000, p. 134).

De maneira que, no âmbito educacional superior, inexiste liberdade plena da atividade econômica, principalmente com referência ao setor particular, em virtude da autorização do serviço público delegado, sua regulamentação e controle praticados pela União, por meio de seu MEC e da Câmara de Educação Superior (CES)/CNE, nos termos dos arts. 209, incisos I e II (BRASIL, 1988) e 16, inciso II, da LDB (BRASIL, 1996b). 0 ensino superior, como questão de ordem pública, enseja sujeição a avaliações rigorosas da qualidade, que aumentam as despesas financeiras das IES privadas, a favor do interesse coletivo constitucional alcançado com o "pleno desenvolvimento da pessoa, seu preparo para o exercício da cidadania e sua qualificação para 0 trabalho" (RANIERI, 2000, p. 137) ${ }^{17}$.

A competência legislativa em questões educacionais decorre do âmbito teleológico ${ }^{18}$, como consequência imediata do princípio constitucional autoaplicável da manutenção plena do padrão de qualidade (BRASIL, 1988, arts. 206, inciso VII, 211, § 1º), proibindo-se abusos mercantilistas no ensino superior privado. Assim, a compreensão da articulação da função regulamentar e de sua força vinculante demanda "raciocínio não mecanicista envolvendo a legalidade própria de administração pública e a legitimidade posta pelo Estado

\footnotetext{
${ }^{17}$ No mesmo sentido, art. 205 (BRASIL, 1988).

${ }^{18}$ Teleologia, na acepção jurídica, é o "estudo especulativo das causas finais e da essência, alcance, aplicação ou fim das normas legais" (NUNES, 1993, p. 811-812). Existe previsão legal da interpretação teleológica, constante no art. 5 Lei de Introdução ao Código Civil (Decreto-Lei nº. 4.657/42): "na aplicação da lei, o juiz atenderá aos fins sociais a que ela se dirige e às exigências do bem comum" (BRASIL, 1942).
} 
Democrático de Direito no qual se postula a participação ativa do cidadão na garantia e defesa de seus direitos" (CURY, 2006, p. 47). No mesmo sentido:

0 zelo pela qualidade do ensino a ser ofertado por instituições públicas e privadas evidencia que tal serviço público deve ser avaliado desde seu processo de autorização. A atuação do poder público, pelos mecanismos de reconhecimento e credenciamento são cruciais para que não haja uma formação de (pseudo) profissionais desqualificados atuantes no mercado profissional ${ }^{19}$.

Em sentido equivalente, a Declaração Mundial sobre Educação Superior no Século XXI: visão e ação, da UNESCO (1998), mostra o ensino superior como sendo o cume do sistema educacional e um serviço público de relevante valor social, pois promove a ação humana a níveis mais elevados.

Como consequência, questões axiológicas derivam do ordenamento jurídico como um todo, determinando obrigações sociais às universidades, desvinculadas do mercado, pois a iniciativa privada pode assumir, com êxito, as matérias inerentes à oferta e à procura, em conformidade com Ranieri (2000). Assim, o ensino, a pesquisa e a extensão nas universidades estão atrelados ao fomento da cidadania, segundo os objetivos fundamentais da República brasileira (BRASIL, 1988).

Ranieri (2000, p. 237) explica que as universidades privadas também são responsáveis pelos objetivos supracitados, mas as distingue das públicas em função da dispensa "do retorno econômico das atividades", o que permite, às últimas, atuação "numa dimensão mais ampla, de natureza reflexiva e integradora, contribuindo para a solução de problemas sociais e o desenvolvimento do conhecimento em áreas de menor retorno econômico". Com isso:

Informadas por estes valores, as finalidades da universidade pública inscritas genericamente no artigo 43 adquirem especificidade própria devido à sua referência ao contexto científico, epistemológico, histórico e social no qual está inserida (o que comprova não só pela integração dos hospitais universitários ao sistema único de saúde, como na diretriz de composição dos colegiados universitários [art. 56], que exige a participação de segmentos da comunidade local e regional, além da institucional) ${ }^{20}$.

Cabe discordar, parcialmente, da referida argumentação. 0 art. 43 LDB indica as finalidades da educação superior, não discriminando se tais objetivos seriam cumpridos exclusivamente pelas universidades públicas, o que enseja a conclusão de que

${ }^{19}$ CURY, 2006, p. 50.

${ }^{20}$ RANIERI, 2000, p. 237. 
qualquer faculdade, centro universitário, ambos de índole pública ou privada, ou, até mesmo, universidade particular detém compromisso social. As primeiras em função do ensino e da extensão e as últimas em virtude do ensino, da pesquisa e da extensão. Os arts. 206, inciso III, e 207 (BRASIL, 1988), em interpretação conjunta com o art. 43 da LDB (BRASIL, 1996b), ensejam tal conclusão. 0 Plano Nacional de Educação (PNE), Lei no 10.172 (BRASIL, 2001b), manifesta expressamente essa natureza jurídica, uma vez que a educação, em geral, é um bem público e, quando prestada por instituições particulares, torna-se serviço de utilidade pública e, por tais motivos, as IES privadas devem assumir postura social diversa da meramente mercantilista. Em sentido equivalente, Sousa (2003), analisando o Plano Diretor da Reforma do Aparelho do Estado, alega que o Poder Executivo Federal manifestou que o Estado só possui a atribuição de financiar e coordenar as políticas públicas, não lhe cabendo executá-las. Portanto, teria que delegar à "iniciativa privada a responsabilidade de diminuir as mazelas provocadas pelo mercado" (BRASIL, 1995a, p. 24).

Apesar do art. 175 CR/88 (BRASIL, 1988) exigir que os serviços públicos sejam criados por lei, mediante iniciativa do Poder Público, e fornecidos diretamente ou em regime de concessão ou permissão $0^{21}$, o art. 209, incisos I e II, CR/88, assegura que 0 ensino pode ser fornecido pelo setor particular, desde que ele se submeta às normas educacionais, à avaliação qualitativa e à expedição de ato administrativo autorizativo, os últimos pela Administração.

Por sua vez, sabe-se que a autorização é uma delegação de serviço público que beneficia a coletividade indiretamente, expedida mediante ato unilateral, precário, por não apresentar garantias ao particular, e com elemento discricionário, dentro dos limites da competência do Poder Público ${ }^{22}$. Ademais de atender a interesses públicos, não demanda investimentos financeiros por parte da Administração. Santamaria Pastor (2000, p. 271272, grifo do autor), após analisar as diferenças entre autorização e concessão, conclui:

Entretanto, a evolução legislativa terminou por extinguir por completo os limites entre a autorização e a concessão; não por falta de rigor técnico das normas, senão por necessidades estritamente politicas:

- existe, como vimos, casos múltiplos de autorização que funcionam com requisitos nos que não preexiste direito algum do particular autorizado (p. ex., a importação de um produto determinado); mas também existem casos de concessões que funcionam sobre atividades que não foram

\footnotetext{
${ }^{21}$ Nesses casos, prévia licitação.

${ }^{22}$ Segundo Pastor (2000, v. 2, p. 273), seria o caso de autorização regulamentada, tendo em vista que "el poder de decisión de la Administración se encuentra vinculado, por cuanto la ley determina las condiciones o requisitos de ejercicio de la actividad intervenida, que la Administración no puede hacer sino comprobar (de manera más o menos mecánica, en función de la objetivación y grado de detalle que los requisitos posean en la norma que los define. Destaca-se que a palavra norma, do mencionado conceito, deve ser entendida como a CR/88 (BRASIL, 1988), a LDB (BRASIL, 1996b), o PNE (BRASIL, 2001b), a Lei $n^{\circ} 10.861$ (BRASIL, 2004b) e o Decreto no 5.773 (BRASIL, 2006a), no ordenamento jurídico brasileiro.
} 
objeto de publicatio, isto é, assumidas como próprias da Administração (p. ex., as velhas concessões para o cultivo do arroz); e atividades declaradas serviços públicos que, todavia, se exercem pelos particulares mediante autorizações, não mediante concessões (p. ex., a educação privada, ou a distribuição de eletricidade) ${ }^{23}$.

Dessa forma, os atos autorizativos de funcionamento de IES não pleiteiam contratos de concessão ou permissão e, consequentemente, dispensam a licitação e a lei instituidora que, em regra, outorga o regime e as qualificações do serviço público, em conformidade com o parágrafo único, do art. 175 CR/88 (BRASIL, 1988). A idiossincrasia precária da autorização acaba por prescindir da existência da lei supracitada e da licitação. Ademais, impossibilita-se a aplicação subsidiária das Leis nº 8.987, de 13 de fevereiro de 1995 (BRASIL, 1995b), e $n^{\circ}$. 8.666, de 21 de junho de 1993 (BRASIL, 1993), às autorizações de ensino, tendo em vista os comandos constitucionais contidos nos arts. 205, 206, incisos II e III, 208, inciso V, e 209, incisos I e II, todos CR/88 (BRASIL, 1988), bem como a própria existência das Leis especificas $n^{\circ} 9.131$ (BRASIL, 1995c), n. 9.394 (BRASIL, 1996b), $n^{\circ} .10 .172$ (BRASIL, 2001b) e 10.861 (BRASIL, 2004b). Portanto, a exemplo da ressalva também apresentada por Di Pietro (2004), quando tratou das autorizações de serviço público relacionadas com o setor de energia elétrica, a educação privada também foge à regra, admitindo a delegação ao segmento particular mediante simples autorização.

Conclui-se que o direito educacional superior deve respeitar as normas de aplicação e hermenêutica comuns ao ramo do direito público, na medida em que se pretende produzir um sistema de ensino qualitativo, autônomo e humanizador, inerente às questões de ordem pública, derivadas das atividades desenvolvidas na educação, com superioridade evidente aos interesses individuais, principalmente aos empresariais. Cabe repetir, ainda, que o Projeto de Lei de Reforma Universitária (BRASIL, 2006c), já no Congresso Nacional, assevera o ensino superior como bem público, o que justifica a natureza jurídica apresentada.

\section{Do poder de polícia sobre a educação superior}

Para se efetivar a supremacia do interesse público sobre o privado, a atividade de supervisão educacional superior deve ser procedida pelas Secretaria de Educação Superior (SESu), nos cursos de graduação e sequenciais, Secretaria de Educação Profissional e Tecnológica (SETEC), nos cursos tecnológicos, e Secretaria de Educação a Distância

\footnotetext{
${ }^{23}$ Tradução livre do original: "Sin embargo, la evolución legislativa ha terminado por difuminar por completo los limites entre la autorización y la concesión; no por falta de rigor técnico de las normas, sino por necesidades estrictamente politicas: - hay, como hemos visto, múltiples supuestos de autorización que operan en supuestos en los que no preexiste derecho alguno del particular autorizado (p. ej., a importar un producto determinado); pero también existen supuestos de concesiones que operan sobre actividades que no han sido objeto de publicatio, esto es, asumidas como propias por la Administración (p. ej., las viejas concesiones para cultivo de arroz); $y$ actividades declaradas servicios públicos que, sin embargo, se ejercen por los particulares mediante autorizaciones, no mediante concesiones (p. ej., la enseñanza privada, o la distribución de eletricidad)".
} 
(SEED), nos cursos à distância. Tais órgãos estão inseridos na estrutura organizacional do MEC. Dessa forma, na supervisão, a Secretaria competente poderá determinar a juntada de documentos adicionais ou a realização de auditoria, para preservar os interesses das partes da relação jurídica educacional e garantir o pleno funcionamento das IES (BRASIL, 2006a, art. 45, §§). Portanto, a atividade de supervisão é manifestação do poder de polícia, já que é uma "prerrogativa de direito público que, calcada na lei, autoriza a Administração Pública a restringir o uso e o gozo da liberdade e da propriedade em favor do interesse da coletividade" (CARVALHO FILHO, 2007, p. 68).

Nesse contexto, de especial relevo a participação dos discentes, docentes e funcionários técnico-administrativos que, por meio de seus órgãos de representação, poderão noticiar aos órgãos de supervisão, antes mencionados, de maneira circunstanciada, a existência de irregularidades no funcionamento de IES ou curso superior.

0 instrumento para se noticiar tais irregularidades é denominado representação, que conterá a qualificação completa do representante, a descrição clara e precisa dos fatos a serem apurados e a documentação para se comprovar o alegado, sem prejuízo de outros elementos relevantes para a investigação do seu conteúdo. Após o recebimento da representação, ela será distribuída, autuada ${ }^{24}$ e numerada pela Secretaria pertinente, para remessa ao Secretário, que analisará sua regularidade formal e determinará a notificação da IES. De maneira que haverá a instauração de um procedimento preliminar para apuração de irregularidades, anterior ao necessário para a aplicação de penalidade, que também poderá ser instaurado de oficio, quando a Secretaria pertinente tiver conhecimento de irregularidade que deva investigar, sanar e, eventualmente, punir. (BRASIL, 2006a, art. 46, §§). Com isso, o art. 47, §§, Decreto no 5.773 (BRASIL, 2006a), explicita o procedimento para apuração de irregularidades, instaurado por representação, que será objeto de futuro estudo, tendo em vista os fins a que este trabalho se destina.

Além disso, também respaldam a natureza jurídica da educação superior privada, antes indicada, as avaliações sobre o sistema federal de ensino, como instrumentos para conseguir a tão desejada qualidade no ensino superior. Assim, o citado art. 46 LDB (BRASIL, 1996b), mantém a prerrogativa do Poder Público de autorizar, reconhecer cursos e credenciar instituições, pela mediação de atos administrativos normativos, resguardando o art. 209 CR/88 (BRASIL, 1988). Salienta-se que tais procedimentos não são objeto deste estudo, devendo ser analisados em momento mais adequado.

Sobre a avaliação das IES, dos cursos superiores e do desempenho acadêmico dos respectivos discentes, 0 art. 58, §§, Decreto no 5.773 (BRASIL, 2006a), determina o cumprimento integral da Lei $n^{\circ} 10.861$ e do SINAES (BRASIL, 2004b). Neste

\footnotetext{
${ }^{24}$ Autuar é "reunir e pôr em ordem as primeiras peças de um processo, ao formar os respectivos autos, sobre o anverso da primeira página de cuja capa se lavra o termo de autuação" (NUNES, 1993, p. 117).
} 
ponto, o citado ato administrativo normativo explicita que o sistema compreende os seguintes processos, destinados a satisfazer suas pretensões e finalidades constitucionais e infraconstitucionais: avaliação institucional interna, avaliação institucional externa, avaliação dos cursos superiores e avaliação do desempenho acadêmico dos estudantes de tais cursos.

0 art. 59, caput e incisos, Decreto ${ }^{\circ} 5.773$ (BRASIL, 2006a) repete as disposições contidas no art. $4^{\circ}$ Lei $n^{\circ} 10.870$ (BRASIL, 2004c), estabelecendo, ainda, que 0 Instituto Nacional de Estudos e Pesquisas Educacionais Anísio Teixeira (INEP) é o órgão responsável pela operacionalização do SINAES, segundo diretrizes formuladas pela Comissão Nacional de Avaliação da Educação Superior (CONAES), de acordo com os arts. $7^{\circ}$ e $8^{\circ}$, inciso II, do mesmo decreto; $6^{\circ}$, incisos I e II, e $8^{\circ}$ da Lei $n^{\circ}$. 10.861 (BRASIL, 2004b).

Em resumo, as avaliações periódicas do SINAES, por meio de indicadores, são realizadas interna e externamente, pelas IES e por comissões de especialistas, designados pelo INEP, respectivamente, sob a coordenação e supervisão da CONAES. As informações para as avaliações serão fornecidas pelas próprias instituições, pelos resultados do Exame Nacional de Desempenho dos Estudantes (ENADE), que demonstram o aprendizado dos estudantes das graduações, pelo censo educacional e pelas avaliações dos cursos superiores e de pós-graduação, realizadas pelo SINAES e pela Coordenação de Aperfeiçoamento do Pessoal de Nível Superior (CAPES), respectivamente, considerando-se também o catálogo de denominações de cursos superiores de tecnologia.

Por fim, a regulamentação e o controle exercidos sobre o fornecimento da educação pelo segmento privado, como um serviço de utilidade pública, cabem a Administração $0^{25}$. A circunstância de tal serviço ser delegado a terceiros, excluídos do âmbito do Poder Público, não subtrai do Estado sua indeclinável e indelegável competência de normatizá-lo, em poder regulamentar, bem como de controlá-lo, mediante os procedimentos administrativos de supervisão e avaliação. Salienta-se a necessária ação estatal segundo parâmetros de eficiência e de atualidade, para que a prestação à população respeite a manutenção plena do padrão de qualidade. Assim, eventual deficiência ou descumprimento de obrigações impostas pelas normas educacionais, entre elas os atos administrativos normativos, por parte do prestador do serviço de utilidade pública, determina a intervenção imediata da Administração delegante, para regularizar sua prestação ou the retirar a função antes exercida. Com isso, a exemplo dos atos e contratos administrativos que concedem a exploração de serviços públicos a terceiros particulares, possibilita-se a alteração unilateral das cláusulas pelo Poder Público e a revogação da delegação quando o interesse coletivo demandar. 0 serviço de utilidade pública destina-se ao público e os seus prestadores nada mais são do que servido-

\footnotetext{
${ }^{25}$ Entenda-se o MEC, suas Secretarias, o CNE, a CONAES, o INEP e a CAPES.
} 
res do coletivo. Como consequência, a finalidade principal do serviço de utilidade pública é servir a população e, apenas secundariamente, fornecer renda ao seu explorador. Nesse contexto, o Estado concedente não pode evadir-se de seu dever de regulamentar, supervisionar, fiscalizar, avaliar e intervir no serviço concedido, sempre que o mesmo não estiver sendo fornecido ao público dentro dos padrões desejáveis de qualidade. Dessa forma, pode também baixar normas de serviço e auditar a situação financeira das mantenedoras de IES.

\section{Considerações finais}

0 Constituinte de 1988 determinou que o sistema privado de ensino deixasse de ser uma concessão do Estado, passando ao regime de autorização e de avaliação de sua qualidade (BRASIL, 1988, art. 209, inciso II). Com isso, instituiu-se a liberdade de aprender e de ensinar, alterando a coexistência de instituições públicas e privadas de educação e convertendo a escola livre em regular, desde que se obedecesse às diretrizes da educação nacional (BRASIL, 1988, art. 22, inciso XXIV) e se submetesse às imposições normativas da autorização e da avaliação de qualidade do Poder Público (BRASIL, 1988, art. 209).

Dessa forma, a partir da evolução constitucional, pôde-se constatar que o ordenamento jurídico brasileiro reconheceu a liberdade de ensino, sob o crivo de um Estado intervencionista e fundante, controlando o sistema educacional por atos administrativos regulatórios, na qualidade de um serviço de utilidade pública.

0 governo de FHC, em resposta aos referidos dispositivos constitucionais, instituiu uma política educacional baseada na avaliação, na qualidade da educação e, para o ensino superior, na autonomia universitária, na melhoria do ensino e na ampliação do espaço das IES privadas do citado nível de educação.

Por sua vez, o art. 46 da LDB (BRASIL, 1996b) mantém a prerrogativa do Poder Público em autorizar, reconhecer cursos e credenciar instituições, pela mediação de atos administrativos normativos, resguardando o art. 209 da CR/88 (BRASIL, 1988).

De maneira que a avaliação de qualidade no ensino ((BRASIL, 1988, arts. 206, inciso VII, 211, § $1^{\circ}$ ), em todos os níveis, é uma questão de ordem pública, indisponivel, que resulta do fornecimento da educação como um direito social, devendo ser assegurada pela Administração Pública.

Por sua vez, a educação tem natureza jurídica de função pública, em conformidade com os arts. 205 e 209, incisos I e II, todos da CR/88 (BRASIL, 1988). Assim, apesar de não ser atividade exclusiva do Poder Público, a educação satisfaz uma pretensão coletiva, o que determina a colaboração mútua do Estado, segmento particular, sociedade e família.

Trata-se, portanto, de um serviço público em sentido amplo, por ser uma ativi- 
dade que a Administração executa sem exclusividade e indiretamente, sob regime preponderantemente público e que satisfaz uma pretensão coletiva. Quando se pensa na educação fornecida pelo segmento privado, ela se efetiva por delegação outorgada em ato administrativo autorizativo.

Aparece, então, como serviço de utilidade pública, uma vez que a Administração declara expressamente sua conveniência à coletividade, permitindo a prestação por autorizatários, que assumem o risco na atividade econômica e podem cobrar seus serviços dos usuários, desde que cumpram as condições previamente regulamentadas e se submetam ao controle exercido pela supervisão e avaliação dos órgãos competentes.

Portanto, o Poder Público surge como gestor principal do sistema educacional, controlando-o, de modo imperativo, para assegurar suas finalidades constitucionais (BRASIL, 1988, art. 205). Ademais, a partir da competência legislativa (BRASIL, 1988, arts. 22, inciso XXIV, 24, inciso IX, e seus $\S \S)$, o sistema educacional necessita da frequente expedição de atos administrativos normativos regulamentares ou interpretativos. Como consequência, houve a aprovação de leis específicas, outorgando função regulamentar ao CNE e ao Ministro de Estado da Educação, Leis no 9.131 (BRASIL, 1995c), 9.394 (BRASIL, 1996b), 10.172 (BRASIL, 2001b) e 10.861 (BRASIL, 2004b), já na vigência da CR/88, o que cumpre com o princípio da legalidade (BRASIL, 1988, art. $5^{\circ}$, inciso II). As Leis no 9.131/95, 9.394/96, 10.172/01 e 10.861/04 concederam ao CNE natureza jurídica de agência reguladora do sistema federal de ensino, vinculando-o às autorizações do serviço de utilidade pública prestado pelo setor privado educacional.

0 fornecimento da educação superior, pelos segmentos público ou particular, incide em dispositivos cogentes, dotados de caracteristicas inerentes ao interesse público indisponivel, tais como os arts. 170, caput e seu parágrafo único, 206, inciso VII, 209, incisos I e II, e 211, § $1^{\circ}$ (BRASIL, 1988) e as Leis no 9.131 (BRASIL, 1995c), 9.394 (BRASIL, 1996b), 10.172 (BRASIL, 2001b) e 10.861 (BRASIL, 2004b), segundo os quais o Poder Público regulamenta as condições da atividade de ensino e a controla por meio dos procedimentos avaliativos primários de autorização de cursos superiores e credenciamento de IES, bem como nos secundários, relativos ao reconhecimento de cursos e às renovações das qualificações antes indicadas, todos previstos no Decreto $n^{\circ} 5.773$ (BRASIL, 2006a) e em outros atos normativos.

Dessa maneira, no âmbito educacional e mediante exercício do poder de polícia, inexiste liberdade plena da atividade econômica, principalmente com referência ao setor particular, em virtude da autorização do serviço público delegado, sua regulamentação e controle praticados pela União, por meio de seu MEC e do CNE, nos termos dos arts. 209, incisos I e II, da CR/88 (BRASIL, 1988), e 16, inciso II, da LDB (BRASIL, 1996b). 0 ensino, como questão de ordem pública, enseja sujeição a avaliações rigorosas da qualidade, que aumentam as despesas financeiras das institui- 
ções privadas, a favor do interesse coletivo constitucional.

Os atos autorizativos de funcionamento de instituições não pleiteiam contratos de concessão ou permissão e, consequentemente, dispensam a licitação e a lei instituidora que, em regra, outorga o regime e as qualificações do serviço público, em conformidade com o parágrafo único, do art. $175 \mathrm{CR} / 88$. A idiossincrasia precária da autorização acaba por prescindir da existência da lei supracitada e da licitação.

Como consequência, a finalidade principal do serviço de utilidade pública é servir a população e, apenas secundariamente, fornecer renda ao seu explorador. Nesse contexto, o Estado concedente não pode evadir-se de seu dever de regulamentar, supervisionar, fiscalizar, avaliar e intervir no serviço concedido, sempre que o mesmo não estiver sendo fornecido ao público dentro dos padrões desejáveis de qualidade. Dessa forma, pode também baixar normas de serviço e auditar a situação financeira das mantenedoras das instituições de ensino particulares.

Em síntese, o principal objetivo da relação educacional é a formação do aluno, 0 que é seu direito individual. Por isso, o interesse público é que a educação fornecida pelas instituições seja de qualidade, tornando efetivo o processo de ensino e de aprendizagem em todos os níveis. Para isso, é de extrema importância que os procedimentos de avaliação das IES assegurem a qualidade das mesmas, seja na autorização, no reconhecimento de cursos ou no credenciamento das referidas instituições, bem como nos procedimentos administrativos de supervisão e avaliação do SINAES.

0 Projeto de Lei de Reforma Universitária deveria explicitar a natureza jurídica aqui indicada, dispensando expressamente a necessidade de lei instituidora e de licitação ao fornecimento de ensino superior particular, de acordo com o enquadramento legal e os privilégios estatuídos pelo ordenamento jurídico. Desse modo, é um excelente momento para se aclarar legalmente as questões apontadas por este estudo. É público e notório que o referido projeto é um exemplo de discussão e participação efetiva da sociedade na Administração Pública, o que respalda o Estado Democrático de Direito, no qual o Estado se submete ao exercício do dever de respeitar os cidadãos, na titularidade de seus direitos individuais e coletivos, onde todos os atos estatais devem ser controlados e fiscalizados, pois o poder emana do povo e em seu nome é exercido, demonstrando, ainda, a prevalência do ordenamento jurídico posto.

Finalmente, ressalta-se que a atuação da União, em matéria de princípios e condutas gerais, não poderá retirar as atribuições especificas dos Estados e Municípios (organizar e gerir os seus sistemas de ensino, conforme art. $211 \mathrm{CR} / 88$ ), na qualidade de entidades autônomas (não por delegação), para atenderem às suas peculiaridades regionais e locais, respectivamente. Tudo isso sob pena de não se formar um sistema nacional de ensino e de enfraquecer a própria Federação brasileira, baseada na des- 
centralização política e administrativa na educação. Cabe destacar que as decisões e ações dos entes políticos periféricos não podem conflitar com as diretrizes e bases instituídas pela entidade central, tendo em vista a sua qualidade de legislação federal principiadora, o que não impede a premente atividade dos primeiros.

Consequentemente, inexiste subordinação entre os sistemas educacionais brasileiros, pois houve uma divisão das competências constitucionais na matéria em questão, ressalvada a hipótese de a União legislar, com finalidade organizacional e para a nação, sobre diretrizes e normas gerais da educação. Portanto, o referido sistema nacional não é superior, hierarquicamente, aos outros, mas se orienta pela $\mathrm{CR} / 88$, LDB e PNE, isto é, toda e qualquer política pública deverá respeitar os princípios e o planejamento nacional instituido por tais normas.

Sem embargo, a LDB regulamentou em nivel basilar o art. $211 \mathrm{CR} / 88$ (BRASIL, 1988), estabelecendo a composição de todos os sistemas de ensino. Desse modo, 0 sistema federal educacional é formado pelas instituições de ensino, de qualquer nivel, providas financeiramente pela União, pelas IES criadas e mantidas pelo setor privado e pelos órgãos educacionais federais, art. 16 da LDB (BRASIL, 1996b). Por sua vez, os sistemas de educação dos Estados membros são compostos por todas as instituições de ensino, mantidas, respectivamente, pelas Administrações Públicas estaduais e pelo Distrito Federal, pelas IES financiadas pelos Municípios, pelas instituições de ensino fundamental e médio do segmento particular e pelos órgãos de educação estaduais e do Distrito Federal (BRASIL, 1996b). Já os sistemas municipais compreendem as instituições do ensino fundamental, médio e de educação infantil, mantidas pelas Administrações Públicas municipais, pelas instituições de educação infantil originadas e sustentadas pela iniciativa privada e pelos órgãos de ensino municipais, art. 18 da LDB (BRASIL, 1996b) ${ }^{26}$. Assim, em tais âmbitos, cada ente federado exercerá seu poder de polícia, seja de supervisão ou de avaliação, sobre seus respectivos sistemas de ensino, preservando-se, em qualquer nivel, a natureza jurídica da educação privada como um serviço de utilidade pública.

\footnotetext{
${ }^{26}$ Ressalta-se a viabilidade de inserção dos Municipios no sistema educacional dos Estados membros ou, ainda, de composição conjunta de um sistema único de educação básica (BRASIL, 1996b, parágrafo único, art. 11). Frisa-se, então, que o sistema municipal jamais poderá supervisionar a educação superior.
} 


\section{Referências}

BANDEIRA DE MELLO, C. A. Curso de direito administrativo. 10. ed. São Paulo: Malheiros Editores, 1998. 665p.

BELLONI, I. A educação superior na nova LDB. In: BRZEZINSKI, I. (Org.). LDB interpretada: diversos olhares se entrecruzam. 8. ed. São Paulo: Cortez, 2003.

BRASIL. Câmara da Reforma do Estado. Plano diretor da reforma do aparelho do Estado. Brasília, DF, 1995a. Disponível em: <http://www.planalto.gov.br/ publi_04/COLECAO/PLANDI.HTM>. Acesso em: 10 jun. 2009.

. Constituição (1988). Constituição da República Federativa do Brasil, 1988. Brasília, DF: Senado Federal, Centro Gráfico, 1988.

Decreto-lei no 4.657, de 4 setembro de 1942. Lei de Introdução ao Código Civil Brasileiro. Diário Oficial [da República Federativa do Brasil], Brasilia, DF, 9 set. 1942. Disponivel em: <https://www.planalto.gov.br/ccivil_03/decretolei/Del4657.htm>. Acesso em: 3 fev. 2008.

. Decreto $\mathrm{n}^{\circ} 2.207$, de 15 de abril de 1997. Regulamenta, para o Sistema Federal de Ensino, as disposições contidas nos arts. 19, 20, 45, 46 e $\S 1^{\circ}, 52$, parágrafo único, 54 e 88 da Lei no 9.394, de 20 de dezembro de 1996, e dá outras providências. Diário Oficial [da República Federativa do Brasil], Brasília, DF, 16 abr. 1997a.

Decreto $n^{\circ}$ 2.306, de 19 de agosto de 1997. Regulamenta, para o Sistema Federal de Ensino, as disposições contidas no art. 10 da Medida Provisória n ${ }^{\circ}$ 1.47739 , de 08 de agosto de 1997, e nos arts. 16, 19, 20, 45, 46 e $§ 1^{\circ}, 52$, parágrafo único, 54 e 88 da Lei no 9.394, de 20 de dezembro de 1996, e dá outras providências. Diário Oficial [da República Federativa do Brasil], Brasilia, DF, 20 ago. $1997 b$.

Decreto no 3.860, de 9 de julho de 2001. Dispõe sobre a organização do ensino superior, a avaliação de cursos e instituições, e dá outras providências. Diário Oficial [da República Federativa do Brasil], Brasilia, DF, 10 jul. 2001a. Disponivel em: <http://www.planalto.gov.br/ccivil_03/decreto/2001/D3860.htm>. Acesso em: 06 abr. 2007.

. Decreto $\mathrm{n}^{\circ} 4.914$, de 11 de dezembro de 2003. Dispõe sobre os centros universitários de que trata o art. 11 do Decreto n ${ }^{\circ} 3.860$, de 9 de julho de 2001, e dá outras providências. Diário Oficial [da República Federativa do Brasil], Brasília, DF, 12 dez. 2003. Disponivel em: <http://www.planalto.gov.br/ccivil_03/decreto/ 2003/D4914.htm>. Acesso em: 8 abr. 2007. 
BRASIL. Decreto $n^{\circ} 5.225$, de $1^{\circ}$ de outubro de 2004. Altera dispositivos do Decreto $n^{\circ} 3.860$, de 9 de julho de 2001, que dispõe sobre a organização do ensino superior e a avaliação de cursos e instituições, e dá outras providências. Diário Oficial [da República Federativa do Brasil], Brasilia, DF, 4 out. 2004a. Disponivel em: <http://www.planalto.gov.br/ccivil_03/_Ato2004-2006/2004/ Decreto/D5225.htm>. Acesso em: 8 abr. 2007.

Decreto $\mathrm{n}^{\circ}$ 5.773, de 9 de maio de 2006. Dispõe sobre o exercício das funções de regulação, supervisão e avaliação de instituições de educação superior e cursos superiores de graduação e sequenciais no sistema federal de ensino. Diário Oficial [da República Federativa do Brasil], Brasilia, DF, 10 maio 2006a. Disponivel em: <http://www.planalto.gov.br/ccivil_03/_Ato2004-2006/2006/ Decreto/D5773.htm>. Acesso em: 18 mar. 2008.

. Decreto $n^{\circ}$ 5.786, de 24 de maio de 2006. Dispõe sobre os centros universitários e dá outras providências. Diário Oficial [da República Federativa do Brasil], Brasilia, DF, 25 maio 2006b. Disponivel em: <http://www.planalto.gov.br/ ccivil_03/_Ato2004-2006/2006/Decreto/D5786.htm\#art4> Acesso em: 08 abr. 2007.

. Emenda Constitucional $n^{\circ} .14$, de 12 de setembro de 1996. Modifica os artigos 34, 208, 211 e 212 da constituição Federal e dá nova redação ao artigo 60 do Ato das Disposições Constitucionais Transitórias. Diário Oficial [da República Federativa do Brasil], Brasília, DF, 13 set. 1996a.

. Lei $n^{\circ}$ 4.024, de 20 de dezembro de 1961. Fixa as Diretrizes e Bases da Educação Nacional. Diário Oficial [da República Federativa do Brasil], Brasília, DF, 27 dez. 1961. Disponivel em: <http://www.planalto.gov.br/ccivil_03/Leis/ L4024.htm>. Acesso em: 13 jan. 2008.

. Lei $n^{\circ}$ 8.666, de 21 de junho de 1993. Regulamenta o art. 37, inciso XXI, da Constituição Federal, institui normas para licitações e contratos da Administração Pública e dá outras providências. Diário Oficial [da República Federativa do Brasil], Brasília, DF, 22 jun. 1993. Disponivel em: <http:// www.planalto.gov.br/ccivil_03/Leis/L8666cons.htm>. Acesso em: 29 jan. 2008.

. Lei $n^{\circ}$ 8.987, de 13 de fevereiro de 1995. Dispõe sobre o regime de concessão e permissão da prestação de serviços públicos previsto no art. 175 da Constituição Federal, e dá outras providências. Diário Oficial [da República Federativa do Brasil], Brasilia, DF, 14 fev. 1995b. Disponível em: <http:// www.planalto.gov.br/ccivil_03/Leis/L8987cons.htm>. Acesso em: 18 ago. 2008. 
BRASIL. Lei $n^{\circ}$ 9.131, de 24 de novembro de 1995. Altera dispositivos da Lei ${ }^{\circ}$ 4.024, de 20 de dezembro de 1961, e dá outras providências. Diário Oficial [da República Federativa do Brasil], Brasilia, DF, 25 nov. 1995c.

. Lei $n^{\circ} 9.192$, de 21 de dezembro de 1995. Altera dispositivos da Lei $n^{\circ}$ 5.540 , de 28 de novembro de 1968, que regulamentam o processo de escolha dos dirigentes universitários. Diário Oficial [da República Federativa do Brasil], Brasilia, DF, 22 dez. 1995d. Disponivel em: <http://www.planalto.gov.br/ ccivil_03/Leis/L9192.htm>. Acesso em: 20 jan. 2008.

. Lei $n^{\circ}$ 9.394, de 20 de dezembro de 1996. Lei de Diretrizes e Bases da Educação Nacional. Diário Oficial [da República Federativa do Brasil], Brasília, DF, Brasilia, DF, 23 dez. 1996b.

. Lei $n^{\circ} .9 .424$, de 24 de dezembro de 1996. Dispõe sobre o Fundo de Manutenção e Desenvolvimento do Ensino Fundamental e de Valorização do Magistério, na forma prevista no art. 60, $\S 7^{\circ}$, do Ato das Disposições Constitucionais Transitórias e dá outras providências. Diário Oficial [da República Federativa do Brasil], Brasília, DF, 1 jan. 1997c.

. Lei $\mathrm{n}^{\circ} 9.784$, de 29 janeiro de 1999. Regula o processo administrativo no âmbito da Administração Pública Federal. Diário Oficial [da República Federativa do Brasil], Brasilia, DF, 1 fev. 1999. Disponivel em: <http:// www.planalto.gov.br/ccivil_03/Leis/L9784.htm>. Acesso em: 20 jan. 2008.

. Lei no 10.172, de 9 de janeiro de 2001. Aprova o Plano Nacional de Educação e dá outras providências. Diário Oficial [da República Federativa do Brasil], Brasilia, DF, 10 jan. 2001. Disponivel em: <http://www.planalto.gov.br/ CCIVIL/LEIS/LEIS_2001/L10172.htm>. Acesso em: 22 out. 2006.

Lei no 10.861, de 14 de abril de 2004. Institui o Sistema Nacional de Avaliação da Educação Superior - SINAES - e dá outras providências. Diário Oficial [da República Federativa do Brasil], Brasilia, DF, 15 abr. 2004. In: BRASIL. Ministério da Educação. Instituto Nacional de Estudos e Pesquisas Educacionais Anísio Teixeira. SINAES: Sistema Nacional de Avaliação da Educação Superior: da concepção à regulamentação. 4. ed. Brasilia: INEP, 2007. p. 139-146.

Lei no 10.870, de 19 mai. 2004. Institui a Taxa de Avaliação in loco das instituições de educação superior e dos cursos de graduação e dá outras providências. Diário Oficial [da República Federativa do Brasil], Brasília, 20 mai. 2004. In: BRASIL. Ministério da Educação. Instituto Nacional de Estudos e Pesquisas Educacionais Anísio Teixeira. SINAES: Sistema Nacional de Avaliação da Educação Superior: da concepção à regulamentação. 4. ed. Brasilia: INEP, 2007. p. 147-148. 
BRASIL. Ministério da Educação. Ministério da Fazenda. Ministério da Previdência e Assistência Social. Ministério da Ciência e Tecnologia. Projeto de Lei de Reforma Universitária. In: . E.M.I. no 015/MEC/MF/MP/MCT. Brasília, DF, 2006c.

Disponivel em: <http://www.sintufsc.ufsc.br/noticias_2006/0619_reforma.pdf>. Acesso em: 29 jan. 2008.

CARVALHO FILHO, J. S. Manual de direito administrativo. 17. ed. Rio de Janeiro: Lumen Juris, 2007.

CUNHA, L. J. C. A Fazenda Pública em juízo. 5. ed. São Paulo: Dialética, 2007.

CUNHA, L. A. 0 ensino superior no octênio FHC. Educação \& Sociedade, Campinas, v. 24, n. 82, p. 37-61, abr. 2003.

CURY, C. R. J. Conselhos de Educação: fundamentos e funções. Revista Brasileira de Política e Administração da Educação, Porto Alegre, v. 22, n. 1, p. 41-67, jan./jun. 2006.

A educação nas constituições brasileiras. In: STEPHANOU, M.; BASTOS, M. H. C. (Org.). Histórias e memórias da educação no Brasil: século XX. Petrópolis: Vozes, 2005a. v. 3.

Educação superior: setor público e iniciativa privada. In: MORHY, L. (Org.). Universidade em questão. Brasilia, DF: Ed. UnB, 2003. v. 1.

. Evolução da educação superior no Brasil: a participação do setor público e da iniciativa privada. Revista Brasileira de Política e Administração da Educação, Brasília, DF, v. 13, n. 1, p. 39-69, jan./jun. 1997a.

. A nova lei de diretrizes e bases da educação nacional: uma reforma educacional?. In: CURY, C. R. J.; HORTA, J. S. B.; BRITO, V. L. A. Medo à liberdade e compromisso democrático: LDB e Plano Nacional da Educação. São Paulo: Ed. do Brasil, $1997 b$.

CURY, C. R. J. 0 público e o privado na história da educação brasileira: concepções e práticas educativas. In: LOMBARDI, J. C.; JACOMELI, M. R. M.; SILVA, T. M. T. (Org.). O público e o privado na história da educação brasileira: concepções e práticas educativas. Campinas: Autores Associados: Histedbr:Unisal, $2005 b$.

DI PIETRO, M. S. Z. Direito administrativo. 17. ed. São Paulo: Atlas, 2004. 
DURHAM, E. R. 0 sistema federal de ensino superior: problemas e alternativas. Revista Brasileira de Ciências Sociais, São Paulo, n. 23, p. 5-27, out. 1993.

MARÇAL, J. Avaliação externa, avaliação interna. In: FIDALGO, F.; MACHADO, L. (Ed.). Dicionário da educação profissional. Belo Horizonte: Núcleo de Estudos sobre Trabalho e Educação, 2000a.

Avaliação institucional. In: FIDALGO, F.; MACHADO, L. (Ed.). Dicionário da educação profissional. Belo Horizonte: Núcleo de Estudos sobre Trabalho e Educação, 2000b.

MEIRELLES, H. L. Direito administrativo brasileiro. 22. ed. São Paulo: Malheiros Editores, 1997.

MOROSINI, M. 0 ensino superior no Brasil. In: STEPHANOU, M.; BASTOS, M. H. C. (Org.). Histórias e memórias da educação no Brasil: século XX. Petrópolis: Vozes, 2005. v. 3.

NUNES, P. R. Dicionário de tecnologia jurídica. 12. ed. Rio de Janeiro: Freitas Bastos, 1993.

PINHEIRO, M. F. S. Publico e o privado na educação brasileira: um conflito na constituinte (1987-1988). 1991. 444 f. Tese (Doutorado em Sociologia) Universidade de Brasilia, Brasília, DF, 1991.

PORTUGAL. Lei $n^{\circ} 62$, de 10 set. 2007. Regime jurídico das instituições do ensino superior. In: CAUPERS, João. Regime jurídico das instituições do ensino superior. Lisboa: Âncora, 2007.

RANIERI, N. B. Educação superior, direito e estado: na Lei de Diretrizes e Bases (Lei no 9.394/96). São Paulo: EDUSP: FAPESP, 2000.

RIBEIRO, M. G. M. Educação superior brasileira: reforma e diversificação institucional. Bragança Paulista: EDUSF, 2002.

SANTAMARÍA PASTOR, J. A. Principios de derecho administrativo. 2. ed. Madrid: Editorial Centro de Estudios Ramón Areces, 2000. v. 2.

SANTOS, M. R. Avaliação de políticas. In: FIDALGO, F.; MACHADO, L. (Ed.). Dicionário da educação profissional. Belo Horizonte: Núcleo de Estudos sobre Trabalho e Educação, 2000. 
SAVIANI, D. A nova lei da educação: trajetória, limites e perspectivas. 9. ed. Campinas: Autores Associados, 2004.

SILVA JÚNIOR, J. R.; SGUISSARDI, V. Reforma do estado e reforma da educação superior no Brasil. In: SGUISSARDI, V. (Org.). Avaliação universitária em questão: reformas do estado e da educação superior. Campinas: Autores Associados, 1997.

SOUSA, J. V. 0 ensino superior privado no Distrito Federal: uma análise de sua recente expansão (1995-2001). 2003. 279 f. Tese (Doutorado em Sociologia) Universidade de Brasilia, Brasília, DF, 2003.

UNESCO. Declaração Mundial sobre Educação Superior no Século XXI: visão e ação. Paris: Conferência Mundial sobre Ensino Superior, 1998. Disponível em: <http://www.interlegis.gov.br/processo_legislativo/copy_of_20020319150524/ 20030620161930/20030623111830>. Acesso em: 7 ago. 2008.

VIEIRA, S. L. Universidade Federal nos anos 80: o jogo da política educacional. 1990. 261 f. Tese (Doutorado em Educação) - Pontifícia Universidade Católica de São Paulo, São Paulo, 1990.

Recebido em: 19/08/2008

Aceito para publicação em: 12/04/2009 
